\title{
ACADM wt Allele
}

National Cancer Institute

\section{Source}

National Cancer Institute. ACADM wt Allele. NCI Thesaurus. Code C82874.

Human ACADM wild-type allele is located in the vicinity of 1 p31 and is approximately 39 $\mathrm{kb}$ in length. This allele, which encodes medium-chain specific acyl-CoA dehydrogenase, mitochondrial protein, plays a role in lipid oxidation. Mutation in the gene is associated with medium-chain acyl-CoA dehydrogenase deficiency. 